\title{
Menedžment dobrega počutja
}

\author{
Maja Kozole* \\ Fakulteta za organizacijske študije v Novem mestu, Ulica talcev 3, 8000 Novo mesto, \\ Slovenija \\ kozole.maja@gmail.com \\ Tjaša Gračner \\ Fakulteta za organizacijske študije v Novem mestu, Ulica talcev 3, 8000 Novo mesto, \\ Slovenija \\ gracner.tjasa@gmail.com
}

\begin{abstract}
Povzetek:
Raziskovalno vprašanje (RV): Kako pomembno je dobro počutje zaposlenih v organizaciji, od česa vse je odvisno in kakšen vpliv ima pri tem vodstvo organizacije?

Namen: Raziskati dejavnike, ki vplivajo na počutje zaposlenih in poiskati načine za vzpostavitev dobre klime v podjetju.

Metoda: S pomočjo integrativnega pregleda literature oziroma že narejenih raziskav na tem področju ter z zbiranjem podatkov iz ZDA, EU in Slovenije.

Rezultati: Rezultati vseh raziskav se ne razlikujejo bistveno, saj je dobro počutje zaposlenih neglede na državo in organizacijo odvisno od podobnih parametrov; dobri medsebojni odnosi, odnos z vodstvom, plačilo, možnost izobraževanja in osebne rasti, izobraževanja, napredovanje in ugodne delovne razmere.

Organizacija: Vpliv na organizacijo je močan, saj organizaciji omogoča doseg boljše delovne klime, manj izostankov z dela zaradi bolezni in posledico manjše stroške ter večjo produktivnost delavcev.

Družba: Dobro počutje ljudi vpliva na večjo pozitivno miselnost in v splošnem na manj stresno življenje ter boljše zdravstveno stanje.

Originalnost: Članke obravnavamo glede na tri različna področja, to so: Evropa, Združene države Amerike in Slovenije. Skupne rezultate opišemo s pomočjo Vennovega diagrama.

Omejitve/nadaljnje raziskovanje: Nadaljnjo raziskovanje bi morali raziskati ukrepe in načine za pomoč organizacijam v smislu inovacije na delovnih mestih za izboljšanje dobrega počutja in produktivnosti delavcev.
\end{abstract}

Ključne besede: dobro počutje, zaposleni, organizacija, stres, zadovoljstvo, vodstvo, zdravje.

\section{Uvod}

Raziskovalno vprašanje članka se navezuje na pomen dobrega počutja menedžerjev in sodelavcev v organizaciji. Dobro počutje dviguje raven kakovosti življenja, zdravja in sposobnosti za uspešno delo, zato je potrebno da poznamo razne pristope za njegovo izboljšanje oziroma smo jih sposobni snovati sami.

* Korespondenčni avtor / Correspondence author 
Dobro počutje lahko obravnavamo v zelo širokem spektru in v splošnem obsega različna zadovoljstva $v$ življenju (splošno zdravstveno stanje, družinsko življenje, prijateljski odnosi, rekreacija, duhovnost, zadovoljstvo z delovnim mestom, ipd.) Pri zaposlenih je dobro počutje ključnega pomena za njihovo zdravje in dobro organizacijsko uspešnost, težje pa ga je ustvariti in vzdrževati. Navadno ni dovolj da zmanjšamo samo negativne dejavnike, ampak moramo povečati tudi pozitivne. Potreben je poseg v delovanje organizacije, družbena razmerja, itd. Zdrava delovna mesta so tista delovna mesta kjer je odnos med delavci spoštljiv in kjer obstajajo organi, ki sodelujejo $\mathrm{v}$ dejavnostih kjer spodbujajo psihično in fizično zdravje sodelavcev. Takšna delovna mesta so namenjena spodbujanju in podpori fizičnega in psihičnega zdravja ter dobrega počutja vseh zaposlenih. Veliko raziskav je pokazalo, da lahko pomanjkanje dobrega počutja na delovnem mestu privede do stresa. (Day \& Nielsen, 2017, str. $1-3)$

\section{Teoretična izhodišča}

Menedžment dobrega počutja temelji na zdravih delovnih mestih. Kljub temu, da mnogim delavcem predstavljajo delovna mesta stres in slabo zdravje, so lahko sama delovna mesta podpora in vir dobrega počutja. Pomembno je imeti zdrave ljudi v službi (prav tako tudi v družbi), je pomoč zaposlenim za izboljšanje in ohranjanje dobrega počutja bistvenega pomena. Ključni namen vsake organizacije je, da sta zdrava delovna sila in dobra organizacijska uspešnost povezani. Organizacije lahko ustvarijo zdrava delovna mesta s pobudami, ki so usmerjene v način organiziranja, oblikovanja dela, družbena razmerja, v vodje, ki so odgovorni za dobro počutje delavcev in v sam razvoj posameznih virov.

Glede na pomen zdravih delavcev in glede na to, da je zdravo delo sila povezano z dobro organizacijsko uspešnostjo, spodbujanje delavcev, mora biti sestavni cilj vseh organizacij. Vendar pa mnogi ne upoštevajo blaginje svojih zaposlenih ali pa celo poslabšajo zdravje le-teh.

Kaj dejansko je sploh dobro počutje in zdravje? Dobro počutje in zdravje sta na splošno opredeljena kot obseg različnih zadovoljstev med življenjem ali delom, ki jih uživa posameznik (to je lahko zadovoljstvo in/ali nezadovoljstvo z družbenim življenjem, družinskim življenjem, rekreacijo, duhovnostjo ali (ne)zadovoljstvo z delom, s plačo, možnostmi napredovanja, sodelavci). Podobno je Svetovna zdravstvena organizacija zdravje opredelila kot »popolno stanje, fizično, duševno in socialno počutje in ne zgolj odsotnost zaradi bolezni ali slabosti« (WHO, 2015 v Day \& Nielsen, 2017, str. 296). Zdravje je potrebno obravnavati celostno in ne vključuje samo negativne dejavnike, temveč tudi pozitivne. (Day \& Nielsen, 2017, str. 296297)

Dobro počutje je sestavljeno iz različnih življenjskih zadovoljitev, ki jih uživajo posamezniki. Je eno izmed ključnih področij za doseganje zastavljenih ciljev organizacije. Če se zaposleni v organizaciji dobro počutijo, so motivirani, napredujejo in si gradijo kariero, so pri svojem delu bolj produktivni in uspešni, posledično ima to tudi pozitivne učinke na organizacijo. V nasprotnem primeru pa ima stres na delovnem mestu negativen učinek na samo poslovanje 
organizacije, v tem položaju pa se zaposleni ne počutijo dobro na svojem delovnem mestu. Literatura na temo menedžmenta dobrega počutja je že vseskozi prisotna na različnih portalih, tudi $\mathrm{v}$ fizični obliki $\mathrm{v}$ knjižnicah in tudi veliko nadrejenih, oseb, ki so zadolžena za izobraževanje o dobrem počutju veliko več posežejo po teh virih, saj si želijo vedno več od svojih zaposlenih. Narejenih je kar nekaj raziskav, ki nudijo vpogled v dejavnike, ki vplivajo na dobro počutje in kako z vpeljavo menedžmenta oziroma ravnateljevanja dobrega počutja uspeti v sami organizaciji. (Day \& Nielsen, 2017, str. 296)

Ameriško združenje medicinskih sester v zdravstveni negi za kritično bolne ljudi je opredelilo 6 načinov za vzpostavitev in vzdrževanje zdravega delovnega okolja: dobro sodelovanje, komunikacijski kanal, učinkovito odločanje, usposobljene osebe, avtentično vodenje in hitro prepoznavanje. Splošna strategija Evropa 2020 vsebuje dva ključna člena; zdravje in dobro počutje. Le tako si lahko prizadevamo k pametni in trajnostni gospodarski rasti, saj je zdravo gospodarstvo odvisno od zdravega prebivalstva. Evropska direktiva o ukrepih za izboljšanje varnosti in zdravja zaposlenih navaja, da je potrebno delo prilagoditi posamezniku in ne obratno. Za izboljšanje dobrega počutja na delovnem mestu so potrebna prizadevanja s strani menedžmenta, vseh zaposlenih in celotne organizacije ter morajo temeljiti na spodbujanju osebnega razvoja posameznika in omogočanju sprejemanja odločitev. (Lorber, 2018, str. 150151)

V organizaciji so izredno pomembne tudi vrednote, ki usmerjajo vedenje podjetja in vplivajo na odnos podjetja do samega sebe in do ostalih ljudi. Vrednote so cilji in pojavi, ki jih zelo cenimo in nas hkrati usmerjajo ter vplivajo na naše vedenje. Vsekakor je za željeno da imajo ljudje vrednote pridobljene na podlagi vedenjskih vzorcev, privzete iz družine, šole ali prijateljev, saj predstavljajo življenjsko gonilo. Ko pa začnemo govoriti o organizaciji in zaposlenih pa je pomembno, da poznamo soglasje med individualnimi in organizacijskimi vrednotami. Organizacijske vrednote največkrat krepijo občutek osebne učinkovitosti, spodbujajo norme, trdo delo, skrb, etiko ter navsezadnje tudi zmanjšujejo raven stresa pri delu. Za uspešno delovanje organizacije se morajo zaposleni zavedati teh vrednot in jih razumeti, kar pa je težko, če so njihove osebne vrednote bistveno različne. Osebne vrednote so globoko zakoreninjeni standardi od katerih je odvisen naš vidik življenja, odnos do sveta in do sebe. (Cimermančič, 2017, str. 89-90)

Zaposleni so najpomembnejši kapital organizacije, zato je pomembno poznati njihovo čustveno inteligenco. Čustva so duševni procesi, kateri vplivajo na naš odnos do pojavov, predmetov in oseb ter označujejo način našega delovanja. Čustvena inteligenca je priučena in pomeni, kako inteligentno uporabljamo čustva, da se $\mathrm{v}$ določenih situacijah pravilno odzovemo. Visoka čustvena inteligenca zaposlenega ima pozitiven vpliv na njegovo funkcionalnost, učinkovitost in uspešnost. Včasih je poslovni svet verjel le IQ testu, danes pa za kar $80 \%$ poslovnega uspeha odgovorna čustvena inteligenca (EQ). (Mervar, 2017, str. 57-60)

Uspešen vodja mora biti dinamičen, pozitiven in mora zaposlene spodbujati pri nalogah ki jih morajo opraviti. Poleg glavnih lastnosti, ki so: čustvena stabilnost, dominantnost, duhovitost, 
etična načela, čustvena inteligentnost, sposobnost izražanja, karizmatičnost; je eno izmed najpomembnejših lastnosti dobrega vodje motiviranje. Vsekakor pa ne smemo pozabiti na to, da mora biti odgovoren in da svoje odgovornosti ne prelaga na druge. (Laznik, 2018, str. 8283)

Vodstvo je vse manj etično, vsaj v bančni industriji. V nadaljevanju bo opisana raziskava med bančnimi delavci v Italiji in Španiji. Zadnja leta so bančna podjetja bila deležna pomanjkanja strokovnih delavcev. Glede na stanje, ki ga večina bank imajo, bodo morale banke vključiti inovacije sektorja, da se premaknejo od tradicionalnih sistemov $\mathrm{k}$ bolj prilagodljivim modelom in odnosom. Ključni izzivi pri temu so predanost in zadovoljstvo delovnega mesta in da je dober odnos med slogom vodenja vodje in pozitivnim odnosom do strokovnih delavcev. Vodja mora vložiti čas in delo v razvoj svojega talenta in v samo organizacijo. Kaj dela oziroma kaj pomeni navdihujoči vodja? Imajo vizijo in višje cilje ter imajo sposobnost pridobiti spoštovanje in spodbujati zaposlene. Navdihujoči vodja daje pomen potrebam in dejanj. So sposobni videti potrebe. Zagotavlja pozitivno energijo, motivacijo za svoje zaposlene, jim izkazuje spoštovanje in se pošteno vede. Predhodne raziskave so pokazale, da je dobro počutje zaposlenih odvisno ne le od fizičnega dela, temveč tudi od psihosocialnega okolja. (Salas-Vallina, Simone, \& Fernández-Guerrero, 2020, str. 162-163)

\section{Metoda}

Predpostavili smo, da obstaja literatura, ki navaja kako je dobro počutje zaposlenih odvisno od menedžmenta. Literatura je na tem področju v zadnjem času močno narasla, rezultati pa kažejo, da je način vodenja zaposlenih ključni faktor zdravja in dobrega počutja zaposlenih (Kelloway \& Barling, 2010, str. 263).

Pregled literature temelji na konceptualni strukturi, ki križno preveri na posamezni, skupinski, vodstveni in organizacijski ravni v smislu menedžmenta dobrega počutja. Literaturo, ki se nanaša na menedžment dobrega počutja smo razvrstili pri principu IGLO (individualna raven, skupinska raven, raven vodje in organizacijska raven), glej tabelo 1.

Z iskanjem po spodaj navedenih ključnih besedah (glej tabelo 2) smo izbrali 19 člankov. Za končen integrativni pregled smo izbrali 11 člankov. Izločili smo vse, ki nisi jasno navajali območja raziskave, ali pa so bili raziskovani na območjih, ki nas ne zanimajo. Za območje ZDA in EU smo uporabili samo tiste, ki so objavljeni v revijah katere faktor vpliva imajo manjši od 1,5. Za območje Slovenije pa smo izbirali članke iz indeksiranih revij. Članke, ki so starejši od 10 let nismo obravnavali, prav tako ne tistih, ki niso raziskovali na vsaj eni od treh področij. Rezultate smo med seboj primerjali znotraj raziskovalnih okvirjev EU in ZDA ter Slovenije. Kritično smo ovrednotili posamezne rezultate in jih primerjali na skupni ravni (EU, ZDA in Slovenija). 
Revija za univerzalno odličnost / Journal of Universal Excellence,

Marec / March 2020, leto / year 9, številka / number 1, str. / pp. 31-47.

Tabela 1. Vizualni pregled kategorizacije

\begin{tabular}{|c|c|c|c|c|c|}
\hline $\begin{array}{l}\text { Raziskovalni } \\
\text { okvir }\end{array}$ & Literatura & $\begin{array}{l}\text { Individualna } \\
\text { raven- } \\
\text { prikazuje } \\
\text { osebne lastnosti } \\
\text { zaposlenih, } \\
\text { njihovo } \\
\text { vedenje, itd. }\end{array}$ & $\begin{array}{l}\text { Skupinska } \\
\text { raven-prikazuje } \\
\text { medosebne } \\
\text { odnose } \\
\text { zaposlenih in } \\
\text { timsko delo }\end{array}$ & $\begin{array}{l}\text { Raven vodja - } \\
\text { prikazuje } \\
\text { kakšen je } \\
\text { pomen vodje, } \\
\text { njegove } \\
\text { značilnosti in } \\
\text { stil vodenja }\end{array}$ & $\begin{array}{l}\text { Organizacijska } \\
\text { raven-obravnava } \\
\text { avtonomijo, } \\
\text { kompenzacije, } \\
\text { ocenjevanja, itd. }\end{array}$ \\
\hline ZDA & $\begin{array}{c}\text { (Shanafelt, } \\
\text { Gorringe, } \\
\text { Menaker, Storz, } \\
\text { Reeves, D., } \\
\text { Buskirk, Sloan, } \\
\text { \& Swensen, } \\
\text { 2015) }\end{array}$ & & & $\mathrm{X}$ & $\mathrm{X}$ \\
\hline ZDA & (Guest, 2017) & $\mathrm{X}$ & $\mathrm{X}$ & & \\
\hline EU & $\begin{array}{c}\text { (Skakon, } \\
\text { Nielsen, Borg, } \\
\text { \& Guzman, } \\
\text { 2010) }\end{array}$ & & & $\mathrm{X}$ & \\
\hline EU & $\begin{array}{c}\text { (Di Fabio \& } \\
\text { Kenny, 2019) }\end{array}$ & $\mathrm{X}$ & & & \\
\hline $\mathrm{EU}$ & $\begin{array}{l}\text { (Salas-Vallina, } \\
\text { Simone, \& } \\
\text { Fernández- } \\
\text { Guerrero, 2020) }\end{array}$ & $\mathrm{X}$ & & $\mathrm{X}$ & $\mathrm{X}$ \\
\hline SLO & (Buzeti, 2016) & $\mathrm{X}$ & $\mathrm{X}$ & & \\
\hline SLO & $\begin{array}{c}\text { (Cimermančič, } \\
\text { 2017) }\end{array}$ & $\mathrm{X}$ & & & $\mathrm{X}$ \\
\hline SLO & $\begin{array}{c}\text { (Šarotar Žižek, } \\
\text { Veingerl Čič, \& } \\
\text { Šebjan, 2017) }\end{array}$ & $\mathrm{X}$ & & $\mathrm{X}$ & \\
\hline SLO & (Blažič, n.d.) & $\mathrm{X}$ & & & $\mathrm{X}$ \\
\hline SLO & (Mervar, 2017) & $\mathrm{X}$ & $\mathrm{X}$ & & \\
\hline SLO & (Laznik, 2018) & & & $\mathrm{X}$ & \\
\hline
\end{tabular}


Tabela 2. Iskanje člankov za določena področja (uporabljene baze podatkov, ključne besede pri iskanju)

\section{ZDA, EU}

Google Učenjak, ScienceDirect
SLO

dLib.si-digitalna knjižnica Slovenije (štiri od šestih člankov so najdeni v reviji za ekonomske in poslovne vede)
Ključne besede:

wellbeing + management, organization, healty + workplaces, human + resource + management, work + stress, employee + commitment, employee + happiness.

\section{Ključne besede:}

dobro + počutje + zaposlenih, zadovoljstvo + zaposlenih, stili + vodenja, zdravje + zaposlenih, vrednote $+v+$ organizaciji.

\section{Rezultati}

\subsection{Rezultati po regijah ZDA, EU in Slovenijo}

\subsubsection{Rezultati raziskav $\mathrm{ZDA}$}

$\mathrm{V}$ zadnjih 30 letih je teorija in raziskovanje upravljanja s človeškimi viri in dobro počutje zaposlenih doseglo velik napredek. Lahko povežemo, da je uspešnost podjetja povezana $\mathrm{s}$ uspešnostjo zaposlenih. Pritiski na delovnih mestih in v širši družbi ustvarjajo vedno večjo grožnjo blaginji zaposlenih. Zato je potreben analitični okvir za človeške vire. Guest (2017, str. 22-23) je mnenja, da lahko informacijska tehnologija privede do preobremenitve dela, motenj na delovnem mestu in vpliva na kakovost obnovitvenega časa. Predlagani analitični model temelji na raziskavah o politikah in praksah na področju človeških virov, za katere se je izkazalo, da delujejo kot predhodniki dobrega počutja zaposlenih in pozitivnih delovnih razmerij. Model temelji na predpostavkah teorije izmenjave, da bi predlagali, da bosta dobro počutje zaposlenih in pozitivno delovno razmerje tako neposredno kot posredno vplivala na uspešnost. To bodo dosegli s svojim vplivom na odnos zaposlenih, motivacijo in vedenje. (Guest, 2017, str. 22-23).

Prvi sklop praks se nanaša na naložbe $\mathrm{v}$ zaposlene. Izboljšanje usposobljenosti $\mathrm{z}$ izobraževanjem in razvojem ter zagotavljanje občutka za prihodnost $\mathrm{v}$ karieri prispevajo $\mathrm{k}$ občutku varnosti in pomoči razvoju lastne učinkovitosti, ki je pomemben predhodnik dobrega počutja.

Drugi sklop se nanaša na zagotavljanje angažiranega dela. Warr-jeva analiza predhodnega dobrega počutja je poudarila pomen priložnosti za nadzor, uporabo spretnosti in razlik pri delu. Tretji sklop je osredotočen na ustvarjanje pozitivnega družbenega in fizičnega okolja in je v literaturi QWL (kakovost delovnega življenja) posebej poudarjen kot predhodnik dobrega počutja in pozitivnih delovnih razmerij. Vključujejo prednostno obravnavo zdravja in varnosti zaposlenih, zagotavljanje priložnosti za socialno interakcijo na delovnem mestu, izogibanje nasiljem in nadlegovanjem, spodbujanje enakih možnosti in raznolikosti, zagotavljanje poštenih nagrad, pogosto povezanih $\mathrm{z}$ visoko osnovno plačo, ter zagotavljanje varnosti zaposlitve. 
Četrti sklop v zvezi s človeškimi viri obravnava vlogo glasu, značilnost, poudarjeno v literaturi o QWL in v HRM (upravljanje z zaposlenimi) z veliko vključenostjo. Ustrezne HR prakse vključujejo obsežno dvosmerno komunikacijo, priložnosti za individualno izražanje mnenja, vključno $\mathrm{z}$ anketami o stališču in ustrezne oblike kolektivne zastopanosti. Te prakse so temeljne značilnosti delovnega razmerja in podpirajo perspektivo zainteresiranih strani, vendar jih pogosto manjka pri modelih, ki so usmerjeni v uspešnost upravljanja človeških virov.

Končni peti sklop odraža pomembnost organizacijske podpore za zagotavljanje dobrega počutja zaposlenih in vključuje kadrovske plače. Sem spadajo participativno, podporno upravljanje in organizacijsko ozračje, ki olajša sodelovanje zaposlenih. Vključuje podporo družinam prijaznim in prilagodljivim delovnim ureditvam.

Model, ki smo ga predhodno opisali vsebuje dve temeljni predlogi. Prva je, da bo prisotnost petih sklopov kadrovskih praks povezana $\mathrm{z}$ večjim počutjem zaposlenim in pozitivnim delovnim razmerjem. Dobro počutje se bo odražalo na psihičnem in telesnem zdravju ter pozitivnih družbenih odnosih pri delu.

Cilj ankete, ki so jo izvedli na kliniki MAYO clinic proceedings v je ugotoviti vpliv vodstva organizacije na strokovno zadovoljstvo in izgorelost posameznih zdravnikov, ki delajo za veliko zdravstveno organizacijo. Oktobra 2013 so anketirali zdravnike in znanstvenike. Za oceno izgorelosti so uporabili potrjena orodja. Zdravniki so tudi ocenili vodstvene lastnosti njihovega neposrednega nadzornika po Likertovi lestvici. Od 3896 anketiranih zdravnikov se jih je odzvalo 2813. Super vizorski rezultati v vsaki od 12 razsežnosti vodenja in sestavljeni rezultat vodstva so močno povezani $\mathrm{z}$ rezultati izgorelosti in zadovoljstva posameznih zdravnikov. (Shanafelt, Gorringe, Menaker, Storz, Reeves, D., Buskirk, Sloan, \& Swensen, 2015, str. 432-440)

Udeleženci raziskave so bili vpoklicani preko elektronskih sporočil univerzitetnih skupin na jugovzhodu ZDA, kjer so anketiranci delali v različnih organizacijah. Vključenih je bilo 148 posameznikov in približno polovica (48 \%) udeležencev je bilo moških. Starost je bila od 24 let do 65 let. 46,2 \% je delala na ravni sodelavcev zaposlenih, 44,9\% so bili nadzorniki, poslovodje ali direktorji. Preostalih $8,5 \%$ pa so bili višji/najvišji nivo. Namen raziskave je bil, ali srečanja na sestankih predstavljajo pomemben kontekst za razumevanje organizacijskega vedenja in odnosa zaposlenih, saj večina zaposlenih preživi veliko časa na sestankih in se pritožujejo nad njimi. V nasprotju pa izpostavljajo pozitivno plat srečanj in trdijo, da lahko srečni sestanki opolnomočijo posameznike, ne pa vse zaposlene. Rezultat te raziskave je bil, da morajo vodje sestankov na koncu srečanja vprašati udeležence o tem, kaj si mislijo o predhodnem sestanku, naj povedo svoja mnenja, izrazijo svoje želje o izboljšanju sestankov, vodja naj uporabljajo »agendo«, torej razpored in se držijo časovnega okvira. (Allen, LehmannWillenbrock, \& Sands, 2016, str. 4340-4345) 


\subsubsection{Rezultati raziskav EU}

Ocenili so, da je delovni stres drugi največji problem, povezan z delovnim okoljem v EU. Vsak četrti prejemnik plač v EU bo v nekem trenutku trpel zaradi stresa na delovnem mestu. Študije so pokazale da je med kar 50\% in $60 \%$ vseh manjkajočih delovnih dni povezano z delovnim stresom. To ne vpliva le na oslabljeno gospodarsko uspešnost, temveč tudi na človeško stisko. Leta 2002 je Evropska komisija poročala, da so v EU stroški zaradi stresa na letni ravni kar 20.000 milijonov evrov. Vodstvo organizacije velja za pomembno vlogo v delovnem okolju, v katerem lahko zaposleni uspevajo in se dobro počutijo. Lahko rečemo da je razpoloženje voditeljev »nalezljivo« za vse zaposlene. Ena izmed raziskav je pokazala da voditelji, ki integritetno pozitivno delujejo na zadovoljstvo na delovnem mestu in posledično je tudi manj stresa med zaposlenimi. Druga raziskava pa je pokazala, da sta sovraštvo in negativna energija vodje povezana $\mathrm{z}$ nezadovoljstvom na delovnem mestu in vpliva na anksioznost zaposlenih. Raziskava daje podporo mnenju, da so pozitivna vedenja vodje, kot so; podpora, povratne informacije, zaupanje in integriteta povezana tako $\mathrm{z}$ afektivnim počutjem zaposlenih kot tudi z manj stresa, zaposlenim pa pomagajo pri obvladovanju stresa. Ugotovili so, da so zaposleni, ki se dobro počutijo na delovnem mestu poročali, da ima njihov vodja bolj aktiven in podporni (transformacijski) slog vodenja. Ljudje se na splošno, vključno z voditelji, po navadi izogibajo depresivnih ljudi in raje posegajo po osebah, ki oddajajo pozitivno energijo, ker je druženje z njimi prijetnejše. Pomemben del psihosocialnega delovnega okolja je tudi stalno soustvarjanje zaposlenih in voditeljev. Poleg tega je posameznikova sposobnost obvladovanja pogojev in zahtev pri delu zelo pomembna. Negativno vedenje vodje negativno vpliva tudi na zaposlene, medtem ko so pozitivno vedenje vodje, podpora vodstva in transformacijsko vodstvo povezani $\mathrm{z}$ visokim afektivnim počutjem zaposlenih in nizkimi stopnjami zaposlenih stres. (Skakon, Nielsen, Borg, \& Guzman, 2010, str. 109-136)

Študija, ki so jo opravili med 524 študenti italijanske univerze prikazuje lastnosti čustvene inteligence in hedonsko (pozitiven efekt, zadovoljstvo v življenju)-eudaimonskim (smisel v življenju) dobrim počutjem. Študija dopolnjuje razumevanje posamezne čustvene vire, ki bi jih bilo mogoče privzgojiti pred samim vstopom na delovno mesto za dobro počutje. Udeleženci raziskave so bili stari med 19 in 34 let. Sodelovalo je 31,1 \% moških in 68,89 \% žensk. Za oceno osebnostnih lastnosti je bil uporabljen vprašalnik Big Five (BFQ), ki je sestavljen iz 132 elementov s 5-točkovno obliko odzivnosti po Likertovi lestvici (1-absolutno napačno do 5popolnoma res). Cilj raziskave je bil preučiti bodoče delavce in lastnosti čustvene inteligence. Ugotovitve kažejo močno pozitivno povezavo med osebami z omejeno mobilnostjo in blaginjo, organizacija pa je trden pokazatelj eudaimonske blaginje. Raziskali so razmerje med PRM (ang. Positive Relational Management) tj. pozitiven relacijski menedžment, in dobrim počutjem (pozitiven vpliv, negativen vpliv, življenjsko zadovoljstvo) skupaj z eudaimosko blaginjo (pomen v življenju, razcvet). Ugotovili so velik vpliv PRM na dobro počutje in na eudaimonsko blaginjo. PRM so postavili kot obetaven konstrukt za razlago in oceno posebnih značilnosti odnosov, ki prispevajo k dobrem počutju skozi celotno življenjsko dobo. Čustvena inteligenca predstavlja pomemben odnos z eudaimonskim počutjem, zlasti samokontrola. Vidiki čustvene inteligence se kažejo na čustvenem izražanju, razumevanju kontekstov, in zato prispevajo $\mathrm{k}$ 
dobrem počutju in nagrajevanju odnosov. Ugotovitve kažejo, da bi lahko bila samokontrola in čustvenost bolj poudarjeni pri vzdrževanju čustvene inteligence med bodočimi delavci. (Di Fabio \& Kenny, 2019, str. 1-6)

Raziskava, ki so jo naredili med 389 delavci, ki delajo v italijanskih in španskih bankah je temeljila na povezavi med navdihujočim vodjem in srečo na delovnem mestu. Rezultati so pokazali, da je navdihujoč vodja ključ pri sreči na delovnem mestu, tako so tudi zaposleni bolj srečni z delom, ki ga opravljajo. Navdihujoči voditelji intelektualno spodbujajo zaposlene in to uporabljajo za povečanje podrejene neodvisnosti in samostojnosti, s tem pa tudi vplivajo na zaposlenega da zapusti cono udobja. Ugotovljeni so bili tudi empirični dokazi, ki so potrdili neposreden, pozitiven učinek inspirativnega vodstva na srečo zaposlenih. Pojem avtonomija je povezana $z$ neodvisnim razmišljanjem in izboljša motivacijo, hkrati pa je ta vrsta motivacije povezana s srečo zaposlenega in angažiranostjo. (Salas-Vallina, Simone, \& FernándezGuerrero, 2020, str. 162-168)

\subsubsection{Rezultati raziskav Slovenija}

Leta 2017 je bila narejena raziskava o vrednotah v različnih organizacijah (proizvodna, storitvena, trgovska podjetja). Slika osebnih in organizacijskih vrednot se razlikuje glede na to v kateri od vrst organizacij je oseba zaposlena. Nekako najpomembnejša vrednota vseh zaposlenih je trdo in vztrajno delo za doseganje zastavljenih ciljev, sledijo prilagodljivost, urejenost, odpuščanje, iniciativnost, gospodarnost in razvoj. Najslabše ocenjena vrednota pa je bila avtonomija, tj. neodvisnost in svobodna izbira ravnanja. Pri proizvodnih podjetjih so v ospredje prišle vrednote katere se navezujejo na spremembe; prilagodljivost, ustvarjalnost in razvoj. Pogled na storitvena podjetja nam poda tiste vrednote, ki so usmerjene na naloge, to so delavnost in disciplina, medtem ko je pri trgovskih podjetjih najpomembnejši odnos; odpuščanje in odprtost. Rezultati so razumljivi, saj $\mathrm{v}$ proizvodnji potrebujemo nenehne izboljšave, storitvena podjetja so zakonsko vezana na čas za dokončanje naloge, trgovska podjetja pa imajo največ stikov s strankami, kjer je potrebno upoštevati njihove želje in ohranjati dober odnos. Zato v organizacijah ni dovolj da imamo izbrane vrednote, ampak mora vodstvo, menedžment in kadrovska služba skrbeti da jih zaposleni sprejmejo in se z njimi poistovetijo, saj le tako posameznik čuti pripadnost organizaciji. Menedžment je tisti, ki drži vse vrvi v svojih rokah in usmerja energijo v pravo smer, osebne vrednote zaposlenih pa morajo biti pri tem čimbolj usklajene z organizacijskimi vrednotami. (Cimermančič, 2017, str. 89-101)

Istega leta je bila narejena raziskava o soodvisnosti posameznika in organizacij v Sloveniji, kjer so analizirali pomen posameznih aktivnosti v organizaciji za zagotavljanje kariernega razvoja in doživljanje zadovoljstva zaposlenega pri delu. Karierna rast je pomemba za zaposlenega, odvisna pa je od individualnih perspektiv in organizacijskih prizadevanj. Kariero zaposleni razumejo kot preplet delovnih in življenjskih izkušenj, hkrati pa si želijo imeti aktivno vlogo pri načrtovanju kariere z delodajalcem. Anketiranci so izpostavili ključne elemente notranjega okolja organizacije, ki vplivajo na karierno pot: sistem vodenja, financiranje izobraževanja/usposabljanja $\mathrm{v}$ organizaciji, možnost izobraževanja/usposabljanja $\mathrm{v}$ 
organizaciji, etičnost poslovanja, povratne informacije o uspešnosti, urejen sistem zagotavljanja in spremljanja delovne uspešnosti. Zaposlenim pa so pomembni tudi elementi, ki združujejo zadovoljstvo zaposlenih in kariero, to so: občutek uspešnosti in učinkovitosti, motiviranost za delo, usklajevanje dela $\mathrm{z}$ družino, dobri medsebojni odnosi, učenje, razvoj sposobnosti. Za zaključek prispevka je navedeno kako pomembno je, da organizacija poskrbi za uspešen in učinkovit menedžment, s katerim bodo zaposleni lažje uresničevali svoja pričakovanja in našli povezavo med svojim poslanstvom in poslanstvom organizacije, posledično pa to vodi v boljšo produktivnost zaposlenih, boljše počutje, večjo predanost delu in v ostale pozitivne učinke. (Blažič, 2017, str. 79-87)

Strokovni prispevek, katerega namen je bil preučiti stanje čustvene inteligentnosti zaposlenih v Sloveniji, podaja rezultate, ki so pokazali, da večina anketiranih pozna pojem čustvena inteligenca in da se zavedajo njenega vpliva na uspešnost. Najbolj razvite sposobnosti ki jih imajo so: družbene spretnosti, sposobnost prepoznavanja lastnih čustev in doživljanje empatije in spretnosti čustvene inteligence. Glede na rezultate bi lahko predpostavili da so zaposleni v slovenskih podjetjih zadovoljni in da so vsa podjetja uspešna, vendar vemo da temu ni čisto tako. (Mervar, 2017, str. 61-66)

Zanimalo nas je tudi kakšne so lastnosti dobrega vodje in kakšen stil vodenja je najprimernejši. Našli smo raziskavo, kjer so sodelovali zaposleni v enem od zdravstvenih zavodov v Sloveniji, niso pa sodelovali vodje. Delavce v zdravstveni negi so z anketo povprašali o zadovoljstvu na delovnem mestu (ocenjevali so z lestvico od 1-nezadovoljni do 5-zadovoljni). Zadovoljstvo z delom je pokazalo najboljše rezultate, in sicer je bila povprečna ocena kar 3,97. Sledilo je zadovoljstvo z odnosi med sodelavci, zadovoljstvo s komunikacijo, z nadrejenim, zadovoljstvo s pogoji dela, $z$ vodstvom delovne organizacije in najslabše ocenjen dejavnik je bil zadovoljstvo z možnostjo napredovanja, ki je dosegel povprečno oceno 3,07. Kot najpomembnejšo veščino, ki jo mora imeti vodja so anketiranci izbrali sposobnost timskega dela. Takoj za njo sledijo še skrb za zaposlene, komunikacijske veščine, načrtovanje ter organizacija, sposobnost motivacije in jasno zastavljeni cilji in naloge. Veščine, ki se zaposlenim zdijo najmanj pomembne pa so vodenje z zgledom, samozavest in nadzor, ampak v bistvu je bila najslabša povprečna ocena zelo visoko po pomembnosti, 4,30 kar pomeni, da je dobro da ima vodja vse naštete veščine. Naslednji vprašalnik je vključeval lastnosti dobrega vodje, kjer so morali anketiranci z lestvico od 1 do 5 izdati kako pomembna je ta lastnost. Izpostavili smo le prvih sedem, ki so se zdele zaposlenim najpomembnejše, to so: odgovornost, poštenost, zanesljivost, poslušanje, komunikativnost, organiziranje in odločnost. Zanimivo odkritje je bilo tudi na področju lastnosti vodenja. Najpomembnejše lastnosti vodenja (povprečne ocene večje od 4,00) se zaposlenim zdijo, da vodja spodbuja podrejene, daje predloge, mnenja, da motivira zaposlene da izrazijo svoje ideje/cilje/načrte, predstavi svoje videnje, analizira problem in predlaga rešitev ter da prevzema odgovornost za uresničevanje ciljev. Z raziskavo so ugotovili tudi kater motivacijski dejavnik vodje najbolj učinkuje pri zaposlenih. Šest motivacijskih dejavnikov vodje (povprečna ocena višja od 4,40), ki zaposlene najbolj motivirajo so: ustvarjanje pozitivne klime v timu, omogočanje dobrih delavnih pogojev, pohvala za dobro opravljeno delo, 
omogočanje napredovanja v primeru dobrih rezultatov, omogočanje izobraževanja in varne zaposlitve. (Laznik, 2018, str. 79-90)

Raziskovali smo tudi psihično dobro počutje zaposlenih na različnih delovnih mestih v slovenskih podjetjih. Zbiranje podatkov je potekalo preko elektronskega vprašalnika, ki je bil izpolnjen s strani respondentov v obdubju med oktobrom 2015 in februarjem 2016. Prva ugotovitev je bila da ni bistvenih statističnih razlik za psihično dobro počutje med moškimi in ženskami. Odgovori na vprašanja so bili podani s 5-stopenjsko Likertovo lestvico (1-sploh se ne strinjam; 5-povsem se strinjam) in vsi so se nahajali v območju med vrednostma 2,5 in 4. Rezultati nakazujejo tudi na to, da bolj kot se posamezniki dobro počutijo v okviru odnosov z vodjem in internega komuniciranja, se srečujejo z novimi izzivi na delovnem mestu, imajo možnost osebne rasti ter razvoja in se lahko sprostijo ko niso več prisotni na delu, manj so izpostavljeni morebitnih boleznim. Ugotovili so tudi pomen stresa, in sicer bolj kot posameznik zaznava stres na delovnem mestu, večjemu številu bolezni je izpostavljen. (Šarotar Žižek, Veingerl Čič, \& Šebjan, 2017, str. 29-37)

V eni izmed slovenskih zavarovalnic so opravili preiskavo o vzdušju v organizaciji in ugotovili težave povezane $\mathrm{z}$ vodenjem, organizacijo dela, nepravično obravnavo, neučinkovito komunikacijo in neravnovesjem med poklicnim in zasebnim življenjem. Ustvarili so program z različnimi ukrepi, ki so vplivali tako na vodstvo kot tudi na zaposlene. Program je vključeval izobraževanja o obvladovanju stresa, delovnih obremenitvah, o izboljšanju komunikacije in odnosov na delovnem mestu. Analiza rezultatov po uvedbi tega programa v podjetju kaže, da se ocena vzdušja v organizaciji izboljšuje. Konstantno se zmanjšuje tudi stopnja zdravstvenega absentizma in v obdobju med 2011 in 2013 so se stroški zdravstvenega absentizma znižali za $8,6 \%$. Vse to lahko pripišemo kot posledico zaradi povečanja zadovoljstva in zavzetosti zaposlenih, večjega sodelovanja med enotami oziroma oddelki. Učinek tovrstnih programov je večplasten, saj lahko s promocijo zdravja zaposlenih vplivamo na nižji zdravstveni absentizem, boljše zdravje zaposlenih, manj nesreč pri delu in hkrati pa so investicija z visokim donosom glede na prihranke zaradi manj delovnih nesreč in zdravstvenih oskrb. Investicije v promocije zdravja naj bi se glede na en vložen evro v dolgoročnem obdobju podjetju povrnile v višini od 1 evra do 11,7 evra. (Buzeti, 2016, str. 148-149)

\subsection{Skupni rezultati}

Ne glede na kontinent in državo organizacije, vsem zaposlenim je skupno, da je njihovo dobro počutje odvisno od motivacije, glej sliko 1 . Ta je najučinkovitejša če prihaja s strani vodstva, vsekakor pa je dobrodošlo da je prisotna tudi med zaposlenimi, ki imajo dober medsebojni odnos in se podpirajo. Faktorji so na splošno med seboj zelo povezani in imajo v večini domino efekt (pomanjkanje enega dejavnika vpliva tudi na pomanjkanje drugih), zato težko rečemo, da je le motivacija tista, ki je ključna in skupna vsem trem regijam. V ospredje stopajo tudi dobri medsebojni odnosi in veščine ter lastnosti vodstva, od katerega je ne malokrat odvisno vzdušje na delovnem mestu. 


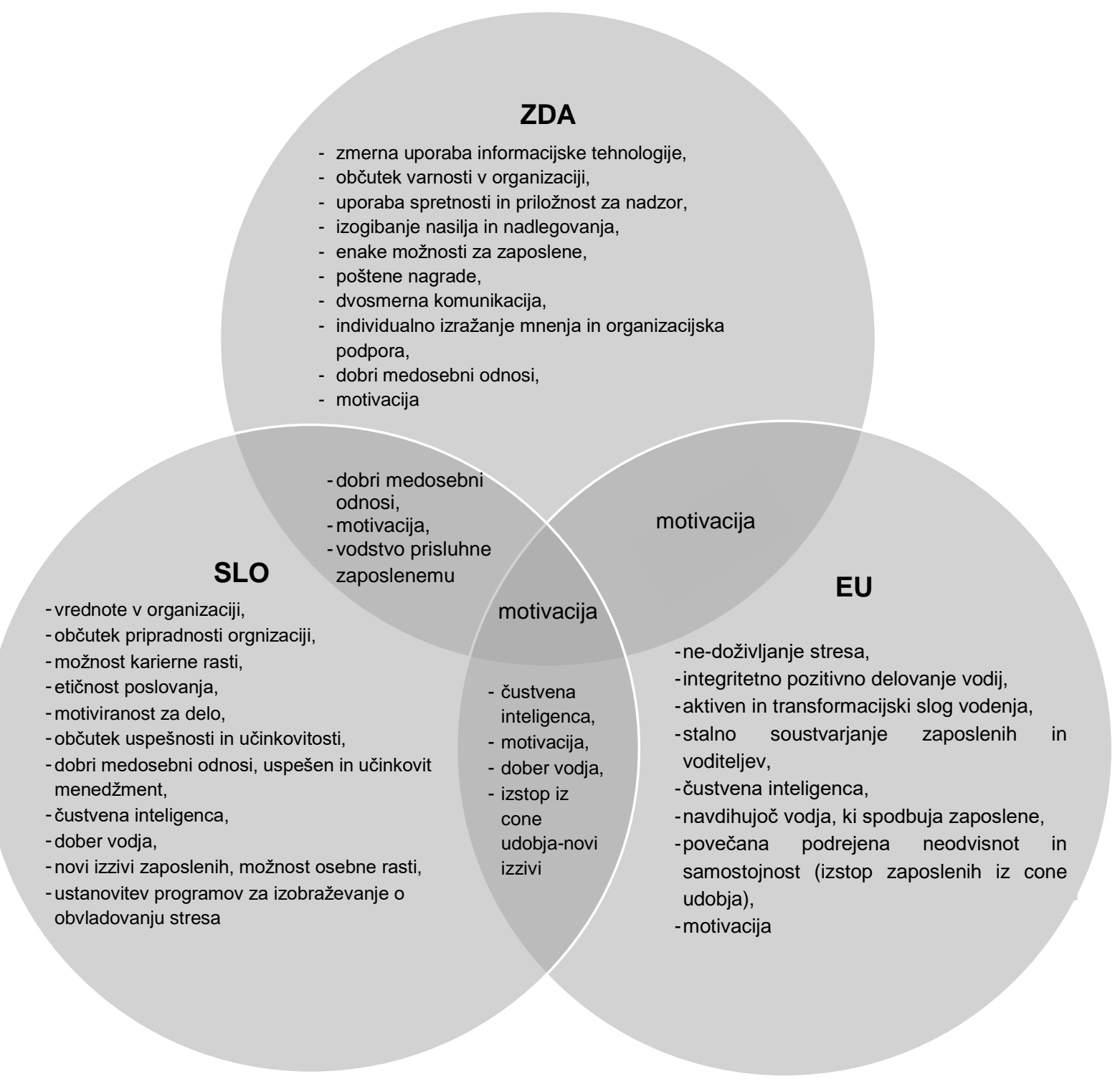

Slika 1. Vennov diagram: Prepoznani faktorji, ki pozitivno vplivajo na dobro počutje zaposlenih.

\section{Razprava}

Kot odgovor na naše raziskovalno vprašanje, lahko rečemo da je dobro počutje zaposlenih v organizaciji izredno pomembno. Dobro počutje je stanje katerega dosežemo le, če upoštevamo tudi vse ostale faktorje, ki vplivajo najn. Glavni fakor, ki je skupen za vsa tri raziskovalna področja je prisotnost motivacije. Motivacija je kot »gorivo« za zaposlenega, da svoje naloge opravlja kvalitetno in uspešno. Vsekakor pa so za to pomembni tudi dobri medosebni odnosi sodelavcev in dober vodja. Vodstvo je tisto, ki usmirja in motivira delavce, zato je pomembno da prepozna težavo in jo zna rešiti. Skozi rezultate smo opazili kakšen način vodenja ustreza zaposlenim, ter katere veščine po njihovem mnenju potrebuje za dobro vodenje. Opazili smo povezavo med uspešnostjo podjetja in uspešnostjo zaposlenih, kako dobro počutje zaposlenih 
vpliva na pozitivno delovno razmerje in organizacijsko klimo. Zaposleni bodo dosegli boljše počutje, če jim bo ponujena ali dovoljena možnost usposabljanja, izobraževanja ali kakršna koli druga oblika osebnega razvoja. Veliko vlogo ima tudi dvosmerna komunikacija, tako med zaposlenimi, kot tudi po hierarhični lestvici organizacije. V raziskavah, ki so se nanašale na ZDA smo opazili, da so uvedli način s katerim vodje po koncu sestanka povprašajo zaposlene o njihovem mnenju in na tak način dobijo povratne informacije, hkrati pa neposredne predloge za izboljšave.

Iz člankov za območje EU, smo ugotovili kako stres vpliva na zaposlene in na celotno organizacijo. Stres je kar drugi največji problem povezan z delovnim okoljem, vemo pa tudi da je stres velikokrat krivec za poslabšanje zdravstvenega stanja. To privede do bolniške odsotnosti z dela kar je za podjetje dodaten strošek. Poročali so tudi, da se delavci počutijo bolje, če imajo za vodjo nekoga ki aktivno in podporno vodi. Temu pravimo transformacijski slog vodenja. V primeru, da vodja oddaja negativno energijo se to negativno odraža tudi na zaposlenih. Prav tako so ugotovili da pozitiven relacijski menedžment vpliva na dobro počutje in eudaimonsko blaginjo. Glede vpliva voditeljev (raven vodstva in organizacijska raven) pa je bilo ugotovljeno, da voditelji ki vodijo v navdihajočem duhu in spodbujajo zaposlene, lažje dosežejo samostojnost zaposlenega in njihov izstop iz cone udobja.

Na področju Slovenije je bilo raziskano, katere vrednote v organizacijah največ štejejo, seveda pa se med seboj razlikujejo glede na vrsto dejavnosti ki jo podjetje izvaja. Neglede na to katere vrednote so postavljen v ospredje, je potrebno da vodstvo, menedžment in kadrovska služba ravna $\mathrm{v}$ skladu z njimi in skrbijo da so zaposleni z njimi poistoveteni. Menedžment mora delovati tako, da zaposlenim dopušča uresničevanje svojih pričakovanj in najdejo povezavo med svojim poslanstvom in poslanstvom organizacije. Na področju Slovenije je bila izvedena tudi raziskava o tem kakšne so lastnosti dobrega vodje. Da lahko vodji rečemo dober vodja, mora imeti kar velik nabor veščin in lastnosti, da bodo dosegli željeno raven uspešnosti podjetja in da se bodo zaposleni pri tem dobro počutili.

Stres in nezadovoljstvo delavcev negativno vplivata na njihovo zdravje, zato so takrat tudi večje možnosti za zdravstvene izostanke z dela, kar pa je dodaten strošek za delodajalca, še posebej v primeru ko pride do izostanka zaradi poškodbe pri delu in je potrebno zdravljenje. Vseeno pa delovno mesto lahko zelo pozitivno vpliva na zaposlenega in je tam deležen spodbud, ki vplivajo na izboljšanje duševnega ali fizičnega zdravja. Ena izmed pomembnih stvari je tudi, da so zaposleni za svoje delo dobro in korektno plačani, da si lahko privoščijo vse potrebno za preživetje sebe in svoje družine, vključno z hobiji, potovanji, itd.

Podjetje ne bo uspešno, če ne bo v njim prevladovala dobro počutje zaposlenih, ter da je uspešnost nagrajena z različnimi nagradami. Zaposleni, ki imajo pozitivno integritetnega vodja, so zadovoljni na delovnem mestu in posledično je tudi prisotnega manj stresa. Upravljanje z dobrim počutjem v podjetju je odvisno predvsem od samega nadrejenega, vodstva, medsebojnih odnosov, družbenega in družinskega življenja, zadovoljstva s plačo, možnostmi napredovanja. 
Pritiski na delovnih mestih in v širši družbi, ter stres ustvarjajo vedno večjo grožnjo blaginji zaposlenih. Zato je tudi potreben analitični okvir za človeške vire. Model temelji na raziskavah o politikah in praksah na področju človeških virov, za katere se je izkazalo, da delujejo kot predhodniki dobrega počutja zaposlenih in pozitivnih delovnih razmerij. Dobro počutje zaposlenih in pozitivno delovno razmerje tako neposredno kot posredno vplivata na uspešnost. Model vključuje pet sklopov praks. Prvi sklop se navezuje na naložbe v zaposlene. Drugi na zagotavljanje angažiranega dela, tretji na ustvarjanje družbenega in fizičnega okolja, četrti je v zvezi z zaposlenimi in zadnji sklop, to je peti sklop pomembnost organizacijske podpore za zagotavljanje dobrega počutja zaposlenih in vključuje plače zaposlenih.

K slabi energiji na delovnem mestu lahko prispeva stres, preveč informacij/dela, slabi medosebni odnosi in zamere, ali pa vodja, ki takšnim težavam sploh ne posveča pozornosti. Razvidno iz vseh raziskav je, da se delavci zavedajo kako pomembno je njihovo dobro počutje na delavnem mestu za uspešnost, dobre rezultate in navsezadnje za njihovo zdravje. Večina anket je bila opravljena na delavcih oziroma ljudeh zaposlenih v organizaciji, zato je vprašanje, v kakšni meri se te problematike zaveda tudi vodstvo. Pomembno se nam zdi, da vodstvo komunicira z zaposlenimi in poizve za morebitne težave, ki zaposlene spravljajo v obup. Vodstvo mora vsekakor poznati kvalitete posameznih zaposlenih, in vedeti koliko informacij in dela jim lahko naloži na dnevni ravni, da to za njih ne bo preveč obremenilno. Poznati mora tudi psihologijo človeka do te mere, da se zaveda vpliva čustvene inteligence in prepozna osebo, ki morda le te nima dodobra razvite. Pomembno je še, da so zaposleni deležni spodbudnih besed in motivacije. Motivacija je lahko verbalna, lahko pa je v obliki denarne nagrade, vsekakor pa bi bilo najbolje da so izvedene obe variante. Nagrajevanje za uspešne dosežke je dobrodošlo predvsem pri mladih, ki si ustvarjajo dom in družino, saj bo dobro plačilo za njih največja motivacija.

\section{Zaključek}

Skozi raziskavo smo ugotovili, da je motivacija zaposlenih glavni faktor, ki se pojavi na vseh treh raziskovanih področjih. Vsekakor pa si ne upamo trditi, da je ta tako pomemben, da lahko druge opustimo ali postavimo v ozadje. Pomembni so vsi dejavniki, ki so jih anketiranci zaznali kot vplivne na njihovo dobro počutje. Za željeno je, da te dejavnike podjetja prepoznajo in posegajo po načinih za izboljšanje delovne klime $\mathrm{v}$ organizaciji . Te ugotovitve so pomembne za vsakršno organizacijo in so jim v opozorilo, da je potrebno vlagati v aktivnosti in v nenehno izboljšanje počutja zaposlenih, saj na ta način lahko zmanjšajo morebitna tveganja za nastanek bolezni, hkrati pa lahko zmanjšamo število bolniških izostankov in s tem povezane stroške. Čeprav so finančne investicije v ta namen za nekatere organizacije lahko velik zalogaj, se le te dolgoročno povrnejo in obrestujejo.

Kot predlog za nadaljnjo raziskovanje je, da bi raziskali kaj vse vpliva na dobro počutje vodij, in bi anketirali samo njih. Tako bi dobro videli njihov pogled na problematiko in bi lahko rezultate primerjali z našimi. Vsekakor je pomembno da se zavedamo, da je dobro počutje na delovnem mestu zelo pomembno, saj človek tam preživi velik del svojega življenja. Na tem 
področju bi bilo potrebno več ustvarjalnosti in inovativnih programov, ki bi to izboljšali. Ni dovolj samo, da delavcem izplačamo mesečno plačilo, za njegovo dobro počutje je potrebno da je informiran z novostmi, motiviran, deležen dobre komunikacije, dobrih medosebnih odnosov in da ima dobre pogoje za delo kjer je poskrbljeno za varnost.

Kot prispevek k stroki lahko pripomnimo, da je veliko stresa na delovnih mestih in bi bilo za željeno, da se podjetja začnejo vključevati v razna izobraževanja o tem, kako kontrolirati svoje vedenje, da ne povzročamo slabe volje drugim. Zdrava delovna mesta so ključ uspešne organizacije. Delovna mesta sama po sebi predstavljajo podporo zaposlenim in so vir dobrega počutja. Dobro počutje in dobra organizacijska uspešnost sta z roko v roki povezani in tako lahko organizacija uspe v vsaki dejavnosti.

Obrtno-območna zbornica Slovenije in ostale zbornice ter združenja s katerimi so organizacije povezane, bi lahko v prihodnje ustvarjale delavnice/izobraževanja kako do boljšega počutja zaposlenih na delovnem mestu in kako imeti zdravo delovno silo na zdravem delovnem mestu.

\section{Reference}

1. Allen, J. A., Lehmann-Willenbrock, N., \& Sands, S. J. (2016). Meetings as a positive boost? How and when meeting satisfaction impacts employee empowerment. Journal of Business Research, 69(10), 4340-4347. https://doi.org/https://doi.org/10.1016/j.jbusres.2016.04.011

2. Blažič, M. (2017). Razumevanje kariere in zadovoljstva z njo v kontekstu organizacije. Revija za ekonomske in poslovne vede, 4(2), 75-91. URN:NBN:SI:DOC-3PJ5VIFU from http://www.dlib.si

3. Buzeti, J. (2016). Ekonomski učinki finančnih investicij v promocijo zdravja in dobrega počutja zaposlenih v delovnem okolju, 14, 139-167. https://doi.org/10.17573/ipar.2016.2-3.07

4. Cimermančič, N. (2017). Analiza vrednot v organizaciji. Revija za ekonomske in poslovne vede, 4(1), 89-105. URN:NBN:SI:DOC-6FB3K4BM from http://www.dlib.si

5. Day, A., \& Nielsen, K. (2017). What Does Our Organization Do to Help Our Well-Being? Creating Healthy Workplaces and Workers. In An Introduction to Work and Organizational Psychology (pp. 295-314). John Wiley \& Sons, Ltd. https://doi.org/10.1002/9781119168058.ch16

6. Di Fabio, A., \& Kenny, M. E. (2019). Resources for enhancing employee and organizational wellbeing beyond personality traits: The promise of Emotional Intelligence and Positive Relational Management. Personality and Individual Differences, 151, 109278. https://doi.org/https://doi.org/10.1016/j.paid.2019.02.022

7. Guest, D. E. (2017). Human resource management and employee well-being: towards a new analytic framework. Human Resource Management Journal, 27(1), 22-38. https://doi.org/10.1111/1748-8583.12139

8. Kelloway, E. K., \& Barling, J. (2010). Leadership development as an intervention in occupational health psychology. Work \& Stress, 24(3), 260-279. https://doi.org/10.1080/02678373.2010.518441

9. Laznik, G. (2018). Lastnosti dobrega vodje in stili vodenja v zdravstveni negi. Revija za ekonomske in poslovne vede, 5(1), 78-99. URN:NBN:SI:DOC-X24P1E4S from http://www.dlib.si

10. Lorber M. (2018). A healthy work environment. Obzornik zdravstvene nege, 5(3), 148152. URN:NBN:SI:DOC-JGIJ3QOS from http://www.dlib.si

11. Mervar I. (2017). Čustvena inteligentnost zaposlenih v organizacijah. Revija za ekonomske in poslovne vede, 4 (1), 57-72. URN:NBN:SI:DOC-5F6SIIXO from http://www.dlib.si 
12. Salas-Vallina, A., Simone, C., \& Fernández-Guerrero, R. (2020). The human side of leadership: Inspirational leadership effects on follower characteristics and happiness at work (HAW). Journal of Business Research, 107, 162-171. https://doi.org/https://doi.org/10.1016/j.jbusres.2018.10.044

13. Šarotar Žižek, S., Veingerl Čič, Ž., \& Šebjan U. (2017). Manager za zdravje - modna muha ali nuja za podjetja. Anali PAZU HD, letnik 3, številka 1, str. 17-38. URN:NBN:SI:DOC-

LLFOXTWV from http://www.dlib.si

14. Shanafelt, T. D., Gorringe, G., Menaker, R., Storz, K. A., Reeves, D., Buskirk, S. J., Sloan, J. A., \& Swensen, S. J. (2015). Impact of Organizational Leadership on Physician Burnout and Satisfaction. Mayo Clinic Proceedings, 90(4), 432-440. https://doi.org/10.1016/j.mayocp.2015.01.012

15. Skakon, J., Nielsen, K., Borg, V., \& Guzman, J. (2010). Are leaders' well-being, behaviours and style associated with the affective well-being of their employees? A systematic review of three decades of research. Work \& Stress, 24(2), 107-139.

https://doi.org/10.1080/02678373.2010.495262

Maja Kozole je oktobra 2019 diplomirala na Fakulteti za kemijo in kemijsko tehnologijo v Ljubljani iz smeri kemijskega inženirstva in pridobila naziv diplomirana inženirka kemijskega inženirstva (UN). Sedaj obiskuje prvi letnik magistrskega študija na Fakulteti za organizacijske študije v Novem mestu, smer menedžment kakovosti. Trenutno ne išče redne zaposlitve in opravlja razna študentska dela preko študentskega servisa. Največ pridobljenih znanj in izkušenj ima na področju dela $\mathrm{v}$ povezavi s kemijo, farmacijo in na splošno $\mathrm{z}$ delom $\mathrm{v}$ laboratoriju.

Tjaša Gračner je študentka prvega letnika podiplomskega študija na Fakulteti za organizacijske študije v Novem mestu, smer menedžment kakovosti. Po predhodni izobrazbi je medijska tehnica, nato pa diplomirana ekonomistka. Ob študiju dela v farmacevtskem podjetju kot referentka. Na Fakulteti za ekonomijo in informatiko Novo mesto je sodelovala na dveh projektih. Prvi je bil z naslovom »Po kreativni poti do znanja: Zaposlitvenopodjetniška akademija«, drugi pa »Daruj krvotvorne matične celice za življenje«. Dalj časa je bila zaposlena kot študentka v podjetju, ki trguje z elektriko in si nabrala veliko izkušenj z delom z ljudmi, kar ji je pri sedanjem delu v veliko pomoč.

\section{Abstract: \\ Well-being Management}

Research Question (RV): How important is well-being of the employees in organization, what depends on it and what impact does the leadership of the organization have on it?

Purpose: To explore the factors that affect the well-being on employees and find the ways to establish a good climate in the company.

Method: With integrative literature review or researches that have been done on this area and with collecting data from USA, EU and Slovenia.

Results: The results of all researches are not significantly different, because the well-being regardless of country and organization dependent on similar parameters.

Good relationships with management, payment, edicational and personal growth opportunities, education, promotion and favorable working conditions.

Organization: The impact on the organization is strong, because it enables the organization to achieve a better working climate, fewer abstences from work due to illness and result in lower costs and increased productivity of workers.

Society: The well-being of people is influenced by a greater positive mindset and generally on less stressful life 
Revija za univerzalno odličnost / Journal of Universal Excellence,

Marec / March 2020, leto / year 9, številka / number 1, str. / pp. 31-47.

and a better health situation.

Originality: We treat articles according to three different areas: Europe, the United States of America and

Slovenia. The combined results are described using the Vennov diagram.

Limitations/Future Research: Further research should explore measures and ways to help organizations in

terms of innovation in workplaces for well-being and productivity of workers.

Keywords: well-being, employees, organization, stress, satisfaction, leadership, health.

Copyright (c) Maja KOZOLE, Tjaša GRAČNER

\section{(c) (†) (?}

Creative Commons License

This work is licensed under a Creative Commons Attribution-ShareAlike 4.0 International License. 